\title{
Collaborative Work Skills for the Beginning IS Professional
}

\author{
Kathy Lynch \\ Monash University, Caulfield, Australia
}

kathy.lynch@sims.monash.edu.au

\begin{abstract}
One of the greatest concerns for many employers recruiting beginning information systems (IS) professionals is not the new recruit's inadequacies in discipline skills or knowledge, but their general lack of the skills required to work effectively within a collaborative team in a changing workplace environment. It is the responsibility of education institutions to prepare beginning IS professionals for this change in how work is done and the change in the workplace for which they are to be employed.

The research reported here examined what industry purports to want and what the literature says they need. Findings from the research identified a number of skills, attitudes and knowledge required for a team member to be effective on a collaborative work effort in the IS profession.
\end{abstract}

Keywords: collaboration, skills, information systems, information technology

\section{Introduction}

Over the last decade the information technology professional workplace has changed; changed in structure, location of its workers, the type of work, the way work is done, the tools used to engage its workers in communication, and the work itself. It will continue to change as technology and expectations grow exponentially. The days of going to the same office location at the same time each day and working with the same colleagues is coming to an end. Kaplan, Docherty and Fitzpatrick $(2000$, p. 2) propose that we are moving away from traditional work that is based on routine processes, individual tasks and isolated work, to work that is focussed on mobility, technology supported, and group and individual projects. The workplace has been re-defined by the International Workplace Studies Program at Cornell University as "a system of loosely-coupled work settings. The diverse settings are linked by the physical movement of employees and the electronic movement of information" (International Workplace Studies Program, 1989).

It is the responsibility of education institutions to prepare beginning IT professionals for this change in how the work is done and the change in the workplace for which they have studied: Their studies should be an antecedent to work and give the students not only the academic capability to be effective in the workforce, but to be part of the team the minute they 'hit the ground' This can be realized if the institutions clearly recognize and plan for the non discipline collabora-

Material published as part of this journal, either on-line or in print, is copyrighted by Informing Science. Permission to make digital or paper copy of part or all of these works for personal or classroom use is granted without fee provided that the copies are not made or distributed for profit or commercial advantage AND that copies 1) bear this notice in full and 2) give the full citation on the first page. It is permissible to abstract these works so long as credit is given. To copy in all other cases or to republish or to post on a server or to redistribute to lists requires specific permission from the publisher at Publisher@InformingScience.org tive skills required by this technological and changing workplace. A collaborative effort that may be spatially and temporally displaced requires skills and attitudes that need to be well formed or polished prior to the students beginning their careers in the IT profession. 
The terms skills and attributes are frequently used interchangeably within the literature examined. Curtis and McKenzie (2002, p. 3) make a useful distinction between these terms. Skills are defined as "the ability to perform a specific task", and attributes are defined as "an observable behaviour performed to a specified level." In this study, both terms are encapsulated in their generic form - that is skills and attributes.

This paper reports on a study that identified the skills required to collaborate effectively in the IT workplace, with a specific focus on the information systems (IS) profession. The first section presents a background into workplace change - the type of work, the location of workers and the spaces they work in, and the importance of collaboration in the work effort. The next section details the study undertaken to identify the skills required to effectively collaborative in the IT workforce. The paper then concludes with a discussion of the findings and future research.

(The work reported is based the author's doctoral thesis to be submitted to the Faculty of Education Monash University, Australia.)

\section{Workplace Change}

Before embarking on the specifics of workplace change in relation to this research, an understanding of change itself is required. According to Cohen-Resenthal (1991. p. 1), change is "a dynamic process that confounds those of us who seek to make better environments for workers whether inside the workplace or in the world at large". Townsend, DeMarie, and Hendrickson (1998, p. 1) claim that "This new workplace will be unrestrained by geography, time, and organizational boundaries; it will be a virtual workplace where productivity, flexibility, and collaboration will reach unprecedented new levels". It is not only the time/space paradigm of work that is changing, but the way we work is also changing.

Advances in information technologies are fostering the interconnectivity and interdependence of the new workplace. Where the work is done or where the workers are located has been defined by Marinos (2001) as the 'alternative workplace' and supplements the traditional workplace. The two places are not distinct; the worker needs to be able to work effectively in either setting. These new workable group spaces can be accomplished through the use of electronic media and computers (Lipnack \& Stamps, 2000, p. 16). According to Duffy and Powell (1997) the new workplace is "more fluid, distributed and dynamic... mobile or nomadic". Change leads to the need for a redesign of the workspace/place itself. Casey $(1999$, p. 25) refers to this as the decentred workplace in which "workers with their laptops computers and mobile phones can work anywhere they have access to a modem, fax or airport".

Work as it has been known for hundreds of years is changing, "Privacy is being replaced with productivity, hierarchy with teamwork, and status with mobility. Work anywhere, anytime is the new paradigm. Work alone, coupled, team. Work in real space or in cyberspace" (Hamilton, 1996, p. 2). Organisations are now 'connected' 24/7, relying on cross-functional self-directed teams, contract or part-time employees, and where lifelong learning, cooperation, collaboration and transferable skills are the requisites for 21 st century workforce. No matter the area or discipline of the profession, there is the expectation that the new employee is 'work ready'. Employers cannot afford, nor generally want, to train their workers in the skills to do the job or the skills required to work as part of a collaborative team (Buchanan et al., 2001, p. 17).

High-performance workplaces need to explore and support collaboration in that "work is becoming more collaborative and less place-dependent, workplace-making is about the appropriate holistic integration of people, process, place, tools and technology to enable work anywhere and anytime." (Rice \& Mitchell-Ketzes, 2002). 
Regardless of the focus of the research conducted by researchers such as Cohen-Resenthal; Townsend, DeMarie and Hendrickson; Lipnack and Stamps, and others, the crux of their research is based on the premise that the $21^{\text {st }}$ century workplace requires effective collaboration between team members for a team effort. The beginning IT professional is therefore required to have the skills and attitudes to be an effective member of the collaborative team.

\section{Collaboration}

Curtis and McKenzie (2002), Marginson (2000) and others have stated that the type of work, where it is done and how it is done is changing. With this change comes a change in the required skills and attributes of employees to be effective members of the workforce. Curtis and McKenzie (2001, p. ix) further imply that with this change, a heavier reliance has emerged on what is commonly referred to as 'soft skills', or "the personal attributes or teamwork, a work ethic, and a preparedness to be flexible and to embrace change". Research conducted by Hager, Crowley and Garrick (2000, p. 5) identified many instances "where workers had been able to improve and refine their soft skills with experience and practice". The skills need to be learnt and re-learnt in the workforce, though employers prefer they are learnt and mastered (to a degree) prior to joining the workforce (Gerber \& Lankshear, 2000).

Working in collaborative teams and in particular ones that are enabled by information and communication technologies (ICT) are at the forefront of the change in how we work. Katzenbach and Smith (1993, p. 5) advocate that "performance challenges that face large companies in every industry, ...demand the kinds of responsiveness, speed, on-line customisation, and quality that is beyond the reach of individual performance. Teams can bridge this gap.". Gerber and Lankshear (2000) claim that working in teams is a criterion for success in the workforce because team work is the smarter way to work. It doesn't stop there, academics and workplace gurus are professing that to be successful you need to be part of a well organised, structured and collaborative team (Bacal, 1996; Lurey \& Raisinghani, 2000).

But what is collaboration? The Merriam-Webster online dictionary defines collaboration as "to work jointly with others or together especially in an intellectual endeavour" (Merriam-Webster, nd). Michael Schrage (1990, p. 6) describes collaboration as "an act of shared creation....and/or...discovery." Throughout the literature there is an interchange of the terms collaboration and cooperation, "The practical reality of collaboration is that it requires a higher order of involvement as well as a different approach to sharing and creating information" (Schrage, 1990, p. 29). Cooperation is "the division of labour among participants, .. an activity where each person is responsible for a portion of the problem solving" (Roschelle \& Teasley, 1991). This description of collaboration is what is referred to in this paper, rather than the 'stapleware' of cooperation.

The ability to collaborate is mentioned in the literature of today relating to graduate attributes, employability skills, and 'soft skills' (Curtis \& McKenzie, 2002; Nielson, 2000; Pont, 2001). Other literature more specifically reports on the skills required to collaborate, but often these are related to the workplace in general. However, at times, course development literature does mention these skills for example in the disciplines of Law and Engineering (Christensen \& Cuffe, 2002; Dodrige, 1999).

One of the problems or failings with the literature, in particular the IS literature, has been the exact nature of these skills and their relationship to working effectively in a collaborative team. If the skills are mentioned at all, they are often hidden and easily overshadowed or overlooked by the essential more technical skills of the discipline. Another issue is seen to be that the phrases used to describe these common skills and attributes are often at a high or macro level and are nondescriptive. They often describe the skills/attributes using one word or a simple phrase leaving the actual details of the skill/attribute up to interpretation. For example, employers require their 
employees to collaborate, communicate and have good interpersonal skills: But what exactly does this mean, and what are the skills that are needed for collaboration, communication and good interpersonal skills?

\section{IS Graduate Skills}

"Information Systems, as an academic field, encompasses two broad areas: (1) acquisition, deployment, and management of information technology resources and services (the information systems function); and (2) development and evolution of technology infrastructures and systems for use in organizational processes (systems development)" (Gorgone et al., 2002, p. 6). It is these areas that academics are required to prepare students to be effective and productive members of the IS profession.

The IS community has identified several constant characteristics of IS professionals. Of these the one that is of greatest interest and relevance to this paper, is "IS professionals must have interpersonal communication and team skills and have strong ethical principles" (Gorgone et al., 2002, p. 6). Others are related to business and world perspectives, analytical and critical thinking skills and information technology solutions.

In the preparation of information systems students for professional employment, the IS academic community over the years has developed curriculum guidelines as the basis for undergraduate accreditation. The guidelines are revised every few years in recognition of constant change within the profession, and change therefore is required in the curriculum that prepares the students for the workforce, "as a result, university-level Information Systems (IS) curricula need frequent updating to remain effective" (Gorgone et al., 2002, p. 4).

The benchmark IS curriculum is currently IS'2002. Table 1 contains excerpts that relate to collaborative skills in the IS'97 (IS'97 Curriculum Taskforce, 1997) and the IS'2002 (Gorgone et al., 2002) curriculum models, and represents the changes over a number of years in curriculum emphasis in the non-discipline areas. The development of the curriculum model expressed in IS'2002 shows that there has been an expansion of the requirement of team working skills and resurgence in communication skills. The literature shows that these go hand-in-hand in the development of a successful collaborative effort.

\section{The Study}

The study undertaken and presented in this paper has two aims:

1. To identify the micro skills and attitudes required to work collaboratively in the IS workforce.

2. To develop a curriculum framework based on these skills for possible implementation into information systems tertiary curriculum.

It is the first aim that is the focus of this paper. 
Table 1 Skills required of the IS graduate

\begin{tabular}{|c|c|}
\hline culum Taskforce, 1997) & IS'2002 (Gorgone, 2002) \\
\hline $\begin{array}{l}\text { Communication } \\
\text { - Accurately observe, note and explain } \\
\text { - Actively listen and express complex ideas in } \\
\text { - } \quad \text { simple terminology } \\
\text { Written, oral and presentation skills }\end{array}$ & $\begin{array}{l}\text { Interpersonal, Communication and Team Skills } \\
\text { Communication } \\
\text { - Listening, observing, interviewing and docu- } \\
\text { menting, } \\
\text { - written, oral and presentation skills }\end{array}$ \\
\hline $\begin{array}{l}\text { Interpersonal relationships } \\
\text { - Effectively work with people of diverse back- } \\
\text { grounds } \\
\text { - Effectively work with people at all corporate } \\
\text { levels } \\
\text { - Lead and facilitate teams in a collaborative } \\
\text { environment } \\
\text { - Empathetically listen and seek synergistic } \\
\text { solutions }\end{array}$ & $\begin{array}{l}\text { Interpersonal } \\
\text { - } \quad \text { listening, } \\
\text { - } \quad \text { motivating, } \\
\text { - } \quad \text { operating in a global, culturally diverse envi- } \\
\text { ronment }\end{array}$ \\
\hline & $\begin{array}{l}\text { Team Work and Leadership } \\
\text { - } \quad \text { Building a team, } \\
\text { - } \quad \text { trusting and empowering, encouraging, } \\
\text { - developing and communicating a vi- } \\
\text { sion/mission, } \\
\text { - } \quad \text { setting and tracking team goals, } \\
\text { - } \quad \text { tegotiating and facilitating, } \\
\text { - } \quad \text { operating in a virtual team environment, } \\
\text { - } \quad \text { being an effective leader }\end{array}$ \\
\hline $\begin{array}{l}\text { Problem Solving } \\
\text { - Formulate creative solutions to simple and } \\
\text { complex problems }\end{array}$ & $\begin{array}{l}\text { Analytical and critical thinking (Organizational } \\
\text { problem solving. Ethics and professionalism, } \\
\text { creativity) } \\
\text { Organizational problem solving } \\
\text { - Problem solving } \\
\text { - Personal decision making } \\
\text { - Critical thinking }\end{array}$ \\
\hline $\begin{array}{l}\text { Professionalism } \\
\text { - Apply personal goal setting and time man- } \\
\text { agement techniques } \\
\text { - Apply personal decision making skulls } \\
\text { - Articulate a personal position and respect the } \\
\text { opinions of others } \\
\text { - Adhere to ethical standards } \\
\text { Assess organizational and societal impacts of } \\
\text { IS }\end{array}$ & $\begin{array}{l}\text { Ethics and professionalism } \\
\text { - } \quad \text { Code of conduct } \\
\text { - } \quad \text { thical theory } \\
\text { - } \quad \text { Leadership } \\
\text { - } \quad \text { Professional - self directed, leadership and } \\
\text { time management } \\
\text { Professionalism - commitment to and com- } \\
\text { pletion of work }\end{array}$ \\
\hline
\end{tabular}

\section{Methodology}

The primary research methodology used in this study has been a qualitative approach because of the open and inquiring nature of the research. The study aimed to gather opinions, perspectives and experiences of information systems (IS) professionals in an attempt to identify and frame the 
collaborative skills and attitudes required by university information systems graduates to work effectively in the professional workforce.

\section{Methods}

Originally, only a focus group session was to be used for the collection of data. During analysis of the data, the findings brought forward more questions, leading to an additional data collection in the form of a questionnaire. This change or shift is not uncommon in perspective-seeking qualitative research (Langenbach, Vaughn \& Aagaard, 1994, p. 96), and is compatible with Tuckman's (1999) 'perspective-seeking' research which is used throughout this study.

The methods used to meet the first aim of the study were;

Focus group session: A focus group session was conducted with a targeted group of information systems (IS) industry professionals, and was used to identify the collaborative skills as perceived by industry. A focus group with a small number of targeted participants was seen as a more effective method rather than one-on-one interviews, as the group session would stimulate discussion, aid in the formation of generalisations and conjecture, and explore opinions.

Questionnaire: One questionnaire was used with a targeted group of information technology (IT) industry professionals, and was used to validate the skills identified by the industry focus group.

\section{Instruments}

The industry focus group session was critical for the study and is therefore presented in detail.

\section{Industry focus group}

The focus group was conducted by an independent facilitator, with the researcher as an observer. The facilitator was briefed to "promote interaction and assure that the discussion remain on the topic of interest" (Stewart \& Shamdasani, 1990, p. 10), but at the same time letting the discussion 'flow'. The facilitator was supplied with an interview schedule based on questions that focused on the following areas:

- Personal understanding of the term collaboration.

- Examples from the workplace where collaboration is critical or important.

- Skills required by IS graduates to effectively work collaboratively in the IT workforce.

- Examples of where collaboration in the IT workforce has worked well.

- Examples of where collaboration in the IT workforce has worked badly.

The volunteer participants were recruited to create a heterogeneous sample of employers of IS graduates. The participants (four male and two female) were from large well known information and communication technologies companies. The companies were heterogeneous in product/services, and each company represented was known to work on collaborative projects, and employ recent information systems graduates. The participants were homogeneous in that they were top-level executives who directly employed recent graduates and/or had vast experience in collaborative projects. The selection of the sample was grounded in the premise that high-level executives from large corporations who have been involved in collaborative projects and were an employer of recent IS graduates, would be able to identify the skills required for a successful collaborative work effort. The focus group being less structured that a one-on-one interview allowed the participants to think more broadly in a situation where there was demonstrably no right or wrong answer or opinion, and therefore simulated valuable discussion. 
The data were recorded in two formats; video with audio, and audio. This was to ensure there was full coverage of the room and reduced the risk of any technical failure. Two sets of video cameras were used with different encoding formats (.avi and .mpeg). The session was one hour in duration and was conducted in a special purpose room where the recording devices and their operation were unobtrusive.

The video and audio data collected were analysed by coding and patterns. A transcription of the session was not undertaken as it was felt that it would not reflect the full character of the session due to the anticipated non-verbal communication and gestures that cannot be accurately transcribed. The analysis was done using the 'cut and paste technique' (Stewart \& Shamdasani, 1990, p. 104) where sections of the session are identified as relevant to the research question/s. Classification system and pattern coding (Miles \& Huberman, 1994, p. 118) were used to correlate same or similar concepts, noting the repeated regularities, and extract any emergent themes/consistencies.

Once the data was analysed to enable 'data reduction' (Miles \& Huberman, 1994, p. 10) a summary report was generated and distributed to the participants for confirmation as to the accuracy of the researcher's interpretation of the focus group session. Feedback from the focus group participants was used to modify or clarify the findings.

\section{Industry questionnaire}

The findings from the industry focus group were transposed into a questionnaire for validation by other IT professionals. The volunteer participants were recruited from a diverse range of IT workplaces; the questionnaire was emailed, together with a request to reply via email or facsimile. Twenty requests to participate were sent, six responses were received.

The questionnaire consisted of twenty-seven closed questions, two open-questions, and focused on the following areas:

- Individual skills required to work collaboratively in the IT workforce.

- Skills required by a team to work collaboratively in the IT workforce.

Within this framework the respondents were asked to rate the level of importance of each of the listed skills in working collaboratively in the IT workforce. The rating system used allocated 4 to indicate very important, 3 to indicate important, 2 to indicate desirable, 1 to indicate unnecessary, and 0 to indicate that the question was unanswered.

The open-ended questions allowed for the respondents to include comments or additional skills they felt were required of a team member to work effectively on a collaborative effort within the IT workplace.

\section{Results}

One of the biggest issues that surfaced from the data collection was the development of a common understanding of the word collaboration. The focus group participants in describing what they meant by collaboration included words and phrases such as "sharing accountability", "beyond project management", "trust", "communication skills" and "inter-personal skills". Often the terms communication and collaboration were interchanged. When asked for further explanation the group agreed that "collaborative skills are really the interpersonal stuff- the communication within the team and how the team then communicates with the client". The consensus of the focus group participants was that "Collaboration for us means $A$, the ability to work with clients, and $B$ the ability to work with colleagues effectively so that at least the whole was at least as great as the sum of the parts". 
The focus group discussion was intense and generated informative data highlighting the general lack of definition and understanding of collaboration, in particular the skills and attitudes required to effectively collaborate. In addition the participants raised a number of issues that are outside the scope of the current research. A number of the comments are reported in Table 2.

The data were correlated and reduced to generate a list of the skills required to effectively partici-

Table 2 Some industry comments

Collaboration worked well? It must have otherwise it wouldn't have been a good project.

What makes a project successful is not the technical things, it is more the success of the collaboration.

Accountability and responsibility loop within the collaborative environment, understanding the requirements and expectations of clients and colleagues, sharing the responsibilities and accountability for the deliverable

The key word is teams; if the collaboration is working effectively then there should be no need to differentiate between the customer or vendor and the consultant. The team is critical to collaboration.

At the end of the day, I won't measure on your individual ability in meeting the objectives, I'll measure you on your ability to work effectively in a team. The strength of the business is working in a team.

Recognise where each team member fits into the team.

If there was one thing that I would like out of any graduate coming in, it would be obtaining a good sense of them self and how they and others fit and interact with each other. They cannot achieve the goal by themselves, they have to work people.

Part of the effective collaboration is then being able as a team work within the boundaries that have been set and still be able to work with each other.

Separating out the technical stuff, the collaborative skills there are coming in are really the interpersonal stuff. It's the things to do with the communication within the team and how the team then communicates out to the client - again its looking for those specific 'people skills'. ... We use to call them people skills/communication skills rather than collaboration skills ...far more people miss out in interviews due to lack of those [communication skills] rather than technical skills

There are a bunch of rules, constraints and expectations surrounding collaboration, more than just the work

Collaboration becomes much more complex when sections of the work are outsourced.

Collaboration within the workplace changes all the time - the support networks change as the teams change

Skill-set changes due to change in project or requirements, the need to up-skill, even if in your own time, this is a hard ask of younger people, but in pressure-cook situations it is necessary - taking accountability for ones own skill level.

More important is how to get the job done rather than the end product, and members representation (that is how they work within the team) is lasting. Not just in achieving outcomes, but how we achieve them. What are our ethics as an organisation, and personally.

To accept challenge, to welcome ambiguity, to be delighted with overcoming challenges (not problems) and to enjoy that in other people too.

Industry is full of ambiguity and change... The group needs to be flexible enough to cope with the constantly changing status of the project.

People are supposed to be multi-skilled - technical skills are going to be much smaller, and interpersonal skills are going to be much greater. 
pate in a collaborative group in the IS workforce. The participants felt that there were two divisions of skills - individual skills, and skills of the team as a whole. This listed was validated by a questionnaire distributed to a number of IT professionals. The skills are shown in Table 3 and Table 4 respectively. The order in which the skills are presented does not imply any priority other than it is the order which emerged during the focus group session with the industry representatives. The mean obtained from the responses from the industry questionnaire is also presented in Table 3 and Table 4.

Of the identified twenty-seven skills and attitudes with a possible mean of 4.00 , sixteen received a mean greater than or equal to 3.14, five have a mean of 3.00 and six have a mean less than 3.00 but greater than or equal to 2.29. This indicates that none of the twenty-seven skills were considered unimportant or unnecessary.

Table 3 Individual collaborative skills as identified by industry

\begin{tabular}{|l|l|}
\hline Skill/attribute & mean \\
\hline 1. Ability to work with clients. & 3.57 \\
\hline 2. Ability to work effectively with colleagues. & 3.83 \\
\hline 3. Ability to interact with others. & 3.86 \\
\hline 4. Ability in managing people. & 2.29 \\
\hline 5. Ability to fit in and move with the organisation's vision. & 2.29 \\
\hline 6. Ability to work with common objectives - team rather than individual. & 3.00 \\
\hline 7. Ability to work "on the fly" and rapidly respond to change. & 3.00 \\
\hline 8. Accountable for own skill set and how they and others fit into the team. & 3.43 \\
\hline 9. Ability to see how they and others fit into the team. & 3.33 \\
\hline 10.Recognition of and respect for the skill sets of others in the team. & 3.14 \\
\hline 11. Has trust in other members of the team - knows when to let go and pass onto others. & 3.14 \\
\hline $\begin{array}{l}\text { 12. Ability to recognise of their position (role/responsibilities) in the team, and the position } \\
\text { (role/responsibilities) of other team members. }\end{array}$ & 3.14 \\
\hline $\begin{array}{l}\text { 13. Personal skills (people related), such as good work habits, attendance cultural and social } \\
\text { sensitivity respect, social confidence. }\end{array}$ & 3.14 \\
\hline $\begin{array}{l}\text { 14. Personal skills (thinking related), such as critical thinking, problem solving strategies, initia- } \\
\text { tive, self-management. }\end{array}$ & 3.43 \\
\hline 15. Communication skills, such as effective reading, writing, speaking, listening, body. & 3.57 \\
\hline 16. Communication skills, such as use of information resources and technology. & 3.33 \\
\hline $\begin{array}{l}\text { 17. Inter-personal skills, such as co-operating, negotiating, directing, confronting, questioning, } \\
\text { adapting. }\end{array}$ & 3.57 \\
\hline \begin{tabular}{l} 
18. Inter-personal skills, such as networking. \\
\hline 19. Ability to understand the context in which the project is situated.
\end{tabular} & 3.00 \\
\hline 20. Ability to recognise when the group is off track. & 3.00 \\
\hline 21. Ability to recognise when the team is not working together. & 3.00 \\
\hline 22. Ability to negotiate and re-negotiate. & 2.86 \\
\hline
\end{tabular}


Table 4 Team collaborative skills as identified by industry

\begin{tabular}{|l|c|}
\hline Skill/attribute & mean \\
\hline 23. Good formal internal communications. & 2.86 \\
\hline 24. Recognition of the completion of a group task, knowing when 'enough is enough'. & 3.29 \\
\hline 25. Ethics - understanding the need to not criticise the team (or members) in public. & 3.29 \\
\hline 26. Flexible. & 2.83 \\
\hline 27. Supportive environment from within the team, and the company. & 3.14 \\
\hline
\end{tabular}

Little response was generated by the industry representatives in the open-ended questions. Nevertheless, other than reinforcing that it is difficult to define ' $g o o d$ work habits' one respondent did add that that it was very important that graduates have 'emotional intelligence' and the 'ability to subjugate oneself and one's ideas to the group (where required)'. The absence of any other comments could be interpreted as the respondents felt that they had nothing substantiative to add and that nothing was omitted.

\section{Discussion}

During the industry focus group session, participants consistently referred to collaboration and the skills required, this was not only when prompted by the facilitator, but in general conversation. They felt that there were numerous skills that encapsulated the meaning of collaboration, and they tried to decompose it into elements. These elements (skills and attitudes) are presented in Tables 3 and 4. All these skills were validated as required skills and attributes by other IT industry professionals. Though the sample size was small for the focus group data collection, the participants was a concentrated representation as their came from companies whom are known to employ recent IS graduates, work on collaborative IS projects and had long histories of working on collaborative IS projects themselves. The confirmation data collection participants were also specifically targeted and came from companies whom work on IT collaborative projects. Having targeted participants reduced 'noise', streamlined and focused thought processes, simulated discussion and engaged the participants in identifying the skills, attitudes and knowledge required for beginning IS professionals to work collaboratively on an IS project within an Australian context.

Many of the skills can be said to be developed through maturity and experience, though the participants did comment that graduates should have some knowledge and experience (even if simulated or protected) during their undergraduate program.

Though the sample size for validating the identified skills was small, the specificity of the participants reduced distractions and added value to the list of identified skills through their ranking of the key areas of working or interacting effectively with colleagues and clients.

Of the twenty-seven identified skills is it interesting to note that a number of these skills are not clearly visible in the IT/IS curricula literature examined. The 'gap' skills have been grouped according to their genesis or focus:

- Team.

9. Ability to see how they and others fit into the team.

19. Ability to understand the context in which the project is situated.

20. Ability to recognise when the group is off track. 
24. Recognition of the completion of a group task, knowing when 'enough is enough'.

- Self

7. Ability to work "on the fly" and rapidly respond to change.

13. Personal skills (people related), such as good work habits, attendance cultural and social sensitivity respect, social confidence.

- Skills

8. Accountable for own skill set and how they and others fit into the team.

10. Recognition of and respect for the skill sets of others in the team.

The highest mean for these skills and attitudes was for skill number 8 (Accountable for own skill set and how they and others fit into the team) with a mean score of 3.43. Skill number 3 (Ability to work effectively with colleagues) scoring the highest overall mean (3.86), and is therefore interpreted as being the most important of those identified.

Of these eight skills and attitudes, three $(8,9$, and 24$)$ were reported by the industry professionals as very important with a mean greater than or equal to 3.33. Each of these skills and attitudes are related to a team effort and highlight the criticality of team inter-relationships, life long learning and maturity in calling a halt to a project or task.

\section{Conclusion}

The Information Systems profession is reported to be a field that involves the "information systems function ... and system development" (by Gorgone et al., 2002, p. 6). In accommodating these areas, IS undergraduates need to effectively collaborate with fellow professionals regardless of time and space to meet the challenges and expectations of both of these functions. Furthermore, the explosion of technology together with a change in the type of work has generated a need to re-address the skills required to work in the IS workplace. Of critical importance is the way in which workers work to achieve 'the product'.

The research reported in the paper presented here, has identified the skills required to work collaboratively in the IS workplace. A number of these skills and attitudes are overly obvious and are currently addressed in the many IS undergraduate programs offered across the globe. However, the research has produced a number of skills and attributes that are not clearly listed in the worldly accepted IS curriculum models; the IS'97 curriculum or the IS'2002 curriculum. This raises a number of questions: Why are these skills not reported in the IS academic literature? How do we develop all of these skills in IS undergraduates? These questions highlight the difficulty in identifying and describing the specifics of the skills and attitudes required to work collaboratively, and further escalates the need to identify, recognise and plan for their development in undergraduate information systems students.

The importance of obtaining these skills and attributes prior to an IS graduate beginning their career in their chosen profession cannot be over emphasised. Nevertheless, it is evident in the research conducted there is a disparity of agreement not so much as to the generality of skills required to collaborate, but in the specificity of these skills. This leads onto the question of 'How can the skills be acquired and developed in undergraduates?' To this end, further research is being conducted into collaborative work skills and the beginning IS professional. This is being formulated through the development of a curriculum framework encompassing the skills and attitudes identified in this project. 


\section{References}

Bacal, R. (1996). The six deadly sins of team-building, The Public Sector Manager. Retrieved September, 2002 from http://www.mts.net/ rbacal/teasin.txt

Buchanan, J., Schofield, K Briggs, C., Considine, G., Hager, P., Hawke, G., et al. (2001). Beyond flexibility: Skills and work in the future. Sydney, NSW Board of Vocational Education and Training.

Casey, C. (1999). The changing contexts of work. In D. Boud \& J. Garrick, (Eds.). Understanding learning at work (pp. 15-28). London: Routledge.

Christensen, S. \& Cuffe, S. (2002) Embedding graduate attributes in law: Why, how, and is it working? Queensland University of Technology. Retrieved March, 2003 from http://www.library.cqu.edu.au/conference/papers/Christensen_Cuffe.pdf

Cohen-Resenthal, E. (1991). Health, ecology, and learning: A perspective on change. University of Michigan. Retrieved March, 2002 from http://www.cfe.cornell.edu/wei/health.html

Curtis, D. \& McKenzie, P. (2001). Employability skills for Australian industry: Literature review and framework development. Australian Council for Educational Research (ACER). Retrieved April, 2003 from www.dest.gov.au/ty/publications/employability_skills/literature_research.pdf

Curtis, D. \& McKenzie, P. (2002). Employability skills for the future. Australia, Department of Education, Science and Training (DEST). Retrieved April, 2003 from http://www.dest.gov.au/ty/publications/employability_skills/final_reprt.pdf

Dillenbourg, P., Baker, M., Blaye, A \& O’Malley, C. (1996). The evolution of research on collaborative learning. In P. Reimann \& H. Spada (Eds.), Learning in humans and machines (pp. 189-211). Oxford: Elsevier.

Dodrige, M. (1999). Generic skill requirements for engineers in the 21 century. 29th ASEE/IEEE Frontiers in Education Conference, San Juan, Puerto Rico, Pittsburg Univeristy.

Duffy, F \& Powell, K. (1997) The new office. New York: Conran Octopus.

Gerber, R. \& Lankshear, C., (Eds.). (2000). Training for a smart workforce. London and NewYork: Routledge.

Gorgone, J., Davis, G., Valacich, J., Topi, H., Feinstein, D., \& Longenecker, H. (2002) IS’2002, Model curriculum and guidelines for undergraduate degree programs in information systems. Retrieved August, 2003 from http://192.245.222.212:8009/IS2002Doc/Main_Frame.htm

Hager, P., Crowley, S., \& Garrick, J. (2000). Soft skills in a hard industry. Sydney, University of Technology, Sydney. Retrieved March, 2003 from http://www.uts.edu.au/fac/edu/rcvet/working\%20papers/0010HagerCrowlGarr.pdf

Hamilton, J. (1996). The new workplace, Business Week. Retrieved March, 2003 from http://www.businessweek.com/1996/18/b34731.htm

IS'97 Curriculum Taskforce. (1997). Model curriculum and guidelines for undergraduate degree programs in information systems: IS within degree programs of a school. Retrieved March, 2003 from http://www.is2000.org/is97/rev/review1.html

International Workplace Studies Program. (1989). Workplace Strategies for the New Economy, IWSP. Retrieved April, 2003 from http://iwsp.human.cornell.edu/research/default.html

Kaplan, S., Docherty, M., \& Fitzpatrick, G. (2000). Stepping into cooperative buildings. Stepping out of Windows. Australasian User Interface Conference, Canberra, ACT Australia.

Katzenbach, J. \& Smith, D. (1993). The wisdom of teams: Creating the high performance organization. Boston: Harvard Business School.

Langenbach, M., Vaughn, C., \& Aagaard, L. (1994). An introduction to educational research. MA, Allyn \& Bacon. 
Lipnack, J. \& Stamps, J. (2000). Virtual teams: People working across boundaries with technology. New York, John Wiley \& Sons.

Lurey, S. \& Raisinghani, M. (2000). An empirical study of best practices in virtual teams. University of Dallas. Retrieved May, 2003 from http://citm.utdallas.edu/Publications/Whitepapers/BestPractices.html

Mankin, D., Cohen, S., et al. (1996). Teams and technology: Fulfilling the promise of the new organisation. Boston: Harvard Business School Press.

Marginson, S. (2000). The changing nature and organisation of work. National Centre for Vocational Education Research. Retrieved May, 2003 from http://www.ncver.edu.au/research/proj/nr6067.pdf

Marinos. (2001). Alternative workplace \& virtual teams. Retrieved May, 2001 from http://www.marinos.com.gr/bbpdf/msg13.pdf

Merriam-Webster Online Dictionary (nd). Retrieved March,2003 from http://www.m-w.com

Miles, M. \& Huberman, A. (1994). Qualitative data analysis. Thousand Oaks, CA: Sage.

Nielsen, A. C. (2000). Research on employer satisfaction with graduate skills. Australia, Department of Employment, Education, Training and Youth Affairs, Australia (DEETYA).

Pont, B. (2001). Skills in the knowledge economy. NSW Board of Vocational Education and Training. Retrieved November, 2002 from http://www.bvet.nsw.gov.au/bvetpdfs/ohpont.pdf

Rice, J. \& Mitchell-Ketzes, S. (2002). Success stories from new workplace. Retrieved August, 2003 from http://www.facilitiesnet.com/bom/Aug02/Aug02facility.shtml

Roschelle, J. \& S. Teasley (1991). The construction of shared knowledge in collaborative problem solving. In C. O'Malley (Ed.), Computer Supported Collaborative Learning. Heidelberg: Springer-Verlag.

Schrage, M. (1990). Shared minds: The new technologies of collaboration. New York: Random House.

Stewart, D. \& Shamdasani, P. (1990). Focus groups: Theory and practice. Newbury Park: Sage.

Townsend, A., DeMarie, S., \& Hendrickson, A.. (1998). Virtual teams: Technology and the workplace of the future. Academy of Management Executive, 12 (3), 17-29.

Tuckman, B. (1999). Conducting Educational Research. Fort Worth TX: Harcourt Brace.

\section{Biography}

Kathy Lynch is a senior lecturer in the Faculty of Information Technology at Monash University, Australia. Kathy has taught in secondary, vocational and tertiary institutions around Australia. Her teaching is in the areas of HCI, studio-based teaching, multimedia systems development, and web databases. Her current research interests lie encompass collaborative work, enabling and emerging technologies, HCI and education. She is undertaking a Doctor of Philosophy in Education, and has a Master in Business Systems (research), multiple Post Graduate Diplomas in IT and Education, and a Bachelor of Education (Secondary).

(http://www.sims.monash.edu.au/staff/klynch/). 